\title{
Uji Porositas dan Kuat Tekan Batako Ringan Berbahan Dasar Limbah Pengolahan Emas (LPE) dengan Filler Pohon Pisang (FPP)
}

\author{
${ }^{1}$ Nola Sumbawaty, ${ }^{2}$ Sukainil Ahzan, ${ }^{3}$ Dwi Sabda Budi Prasetya
}

Program Studi Pendidikan Fisika, Fakultas Pendidikan Matematika dan IPA, Institut Keguruan dan Ilmu Pendidikan (IKIP) Mataram, Jl. Pemuda 59A, Mataram 83125, Indonesia

Email:nolasumbawaty04@gmail.com

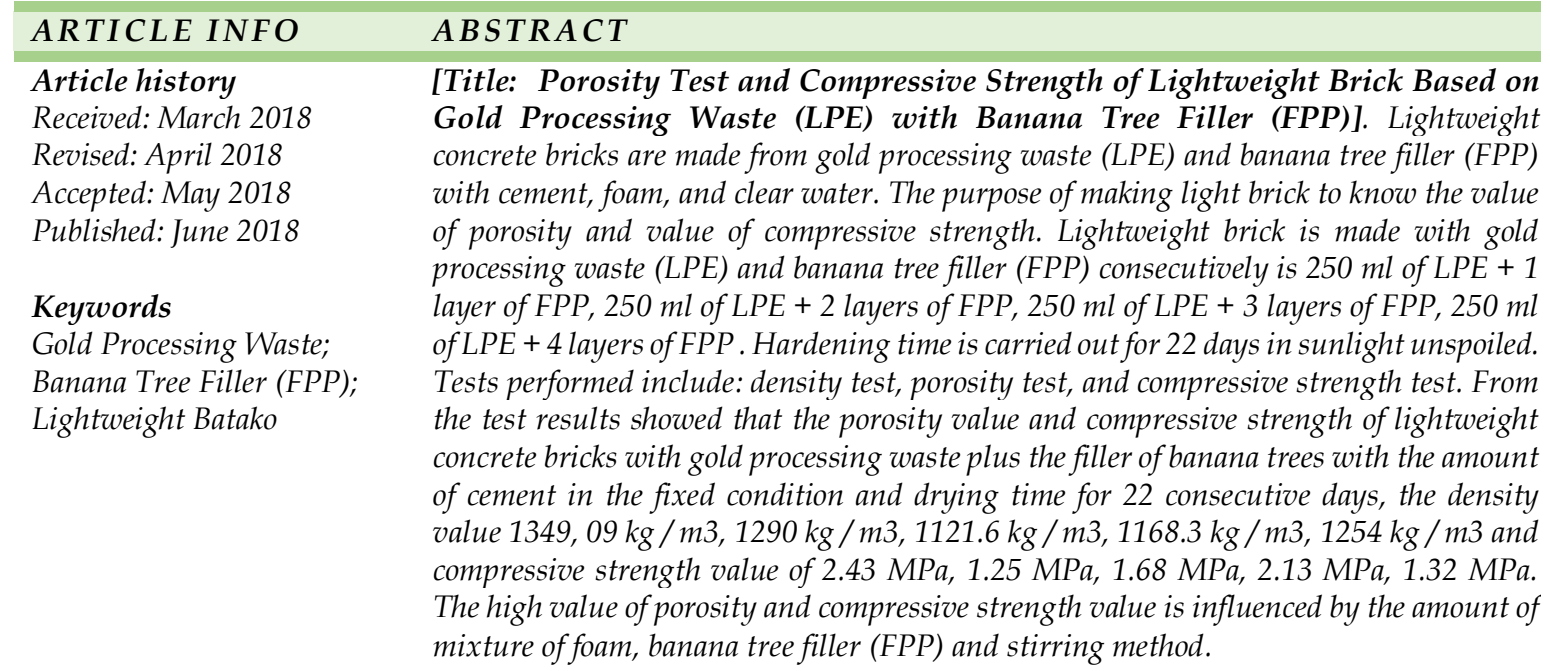

INFO ARTIKEL
Sejarah Artikel
Dikirim: Maret 2018
Direvisi: April 2018
Diterima: Mei 2018
Dipublikasi: Juni 2018
Kata kunci
Limbah Pengolahan
Emas;
Filler Pohon Pisang (FPP);
Batako Ringan

\section{ABSTRAK}

Telah dilaksanakan pembuatan batako ringan yang terbuat dari bahan dasar limbah pengolahan emas (LPE) dan filler pohon pisang (FPP) dengan bahan penunjang semen, foam, dan air jernih. Tujuan pembuatan batako ringan untuk mengetahui nilai porositas dan nilai kuat tekan. Batako ringan dibuat dengan limbah pengolahan emas (LPE) dan filler pohon pisang (FPP) berturut adalah 250 $\mathrm{ml} \mathrm{LPE} \mathrm{+} 1$ lapis FPP, $250 \mathrm{ml} \mathrm{LPE} \mathrm{+} 2$ lapis FPP, $250 \mathrm{ml} \mathrm{LPE}+3$ lapis FPP, $250 \mathrm{ml}$ $\mathrm{LPE}+4$ lapis FPP. Waktu pengerasan dilakukan selama 22 hari di dalam ruangan yang tidak terkena sinar matahari. Pengujian yang dilakukan meliputi: uji densitas, uji porositas, dan uji kuat tekan. Dari hasil pengujian menunjukkan bahwa nilai porositas dan kuat tekan batako ringan dengan limbah pengolahan emas ditambah dengan filler pohon pisang dengan jumlah semen pada kondisi tetap dan waktu pengeringan selama 22 hari berturut-turut, nilai densitas 1349, $09 \mathrm{~kg} / \mathrm{m}^{3}, 1290 \mathrm{~kg} / \mathrm{m}^{3}, 1121,6 \mathrm{~kg} / \mathrm{m}^{3}, 1168,3 \mathrm{~kg} / \mathrm{m}^{3}, 1254 \mathrm{~kg} / \mathrm{m}^{3}$ dan nilai kuat tekan 2,43 MPa, 1,25 MPa, 1,68 MPa, 2,13 MPa, 1,32 MPa. Tinggi rendahnya nilai porositas dan nilai kuat tekan dipengaruhi oleh banyaknya campuran foam, filler pohon pisang (FPP) dan cara pengadukan.

How to Cite this Article? Sumbawaty, N., Ahzan, S., \& Prasetya, D., S., B. (2018). Uji Porositas dan Kuat Tekan Batako Ringan Berbahan Dasar Limbah Pengolahan Emas (LPE) dengan Filler Pohon Pisang (FPP). Jurnal Penelitian dan Pengkajian Ilmu Pendidikan: eSaintika, 1(2), 87-93. 


\section{PENDAHULUAN}

Pencemaran lingkungan dari hasil limbah pengolahan emas meresahkan masyarakat karena penggunaan bahan berbahaya beracun (B3) yaitu merkuri (Hg) dan potasium. Pencemaran tersebut terjadi ketika sebagai merkuri $(\mathrm{Hg})$ yang digunakan sebagian bahan pengikat emas terbuang bersama air limbah pencucian ke lokasi pembuangan baik ditanah maupun di sungai.

Batang pisang merupakan limbah dari tanaman pisang yang telah ditebang untuk diambil buahnya. Batang pisangnya dibuang atau ditumpuk dan membusuk di kebun serta pemanfaatan batang pisang yang terbatas.

Melihat permasalahan di atas, maka dalam penelitian ini mengembangkan penelitian mengenai pemanfaatan limbah pengolahan emas (LPE) dan batang pisang sebagai bahan dasar pembuatan batako ringan yang digunakan sebagai konstruksi. Oleh karena itu penulis mengambil judul "Uji Porositas Dan Kuat Tekan Batako Ringan Berbahan Dasar Limbah Pengolahan Emas (LPE) Dengan Filler Pohon Pisang (FPP)".

Penelitian ini bertujuan untuk (1) mengetahui cara mengolah limbah pengolahan emas (LPE) menjadi batako ringan dan (2) mengetahui pengaruh penambahan filler pohon pisang pada pembuatan batako ringan serta nilai densitas dan nilai kuat tekan batako ringan berbahan dasar limbah pengolahan emas dan filler pohon pisang. Hasil penelitian ini diharapkan dapat (1) memaksimalkan pemanfaatan LPE yang sangat banyak jumlahnya untuk digunakan sebagai bahan dasar dalam pembuatan batako ringan dan (2) menambahkan keragaman ilmu pengetahuan bahwa filler pohon pisang memiliki unsur penting dalam pembuatan batako ringan.

\section{Kajian pustaka}

\section{Limbah pengolahan emas (LPE)}

Keberadaan LPE dalam dunia pertambangan tidak bisa dihindari dari penggalian atau penambangan yang dilakukan hanya $30 \%$ bijih menjadi produk utama, produk sampingan, sisanya menjadi LPE. LPE merupakan limbah hasil pengolahan bijih yang sudah dianggap tidak berpotensi lagi untuk dimanfaatkan.

Filler pohon pisang (FPP)

Filler (penguat) yang berfungsi sebagai penanggung beban utama. Penambahan serat batang pisang sebagai filler atau material campuran batako ringan dapat memperkuat batako ringan yang dilihat dari jenis serat yang dimiliki serta kandungan yang terdapat di dalam batang pisang.

\section{Batako ringan}

Batako atau juga disebut bata beton ialah suatu jenis unsur bangunan yang berbentuk bata yang dibuat dari campuran bahan perekat hidrolis atau sejenisnya, air dan agregat, dengan atau tanpa bahan tambah lainnya yang tidak merugikan sifat beton itu (PU, 1989).

Material dinding dari batako ini umumnya dibuat dari campuran semen dan pasir kasar yang dicetak padat atau dipress. Selain itu ada juga yang membuatnya dari campuran batu tras, kapur dan air. Bahkan kini juga beredar batako dari campuran semen, pasir dan batubara. Dengan bahan pembuatan seperti yang telah disebutkan, batako memiliki kelemahan yaitu kekuatannya lebih rendah dari bata 
merah, sehingga cenderung terjadi keretakan dinding, terutama jika bagian kosongnya tidak diisi dengan adukan spesi. Pemakaian material batako untuk dinding juga membuat bangunan lebih hangat bahkan cenderung pengap dan panas, tidak seperti bata merah yang terbuat dari material tanah. Batako cenderung lebih ringan daripada bata merah. Teksturnya pun terlihat lebih halus dari bata merah (Wikipedia, 2019).

Menurut Tjokrodimulyo (2007), beton disebut ringan apabila beratnya kurang dari $1800 \mathrm{~kg} / \mathrm{m}^{3}$. Batako di kualifikasi menjadi dua golongan, yaitu batako ringan dan batako normal. Batako normal tergolong ke dalam batako yang memiliki densitas sekitar $2200 \mathrm{~kg} / \mathrm{m}^{3}-2400 \mathrm{~kg} / \mathrm{m}^{3}$ sedangkan batako ringan adalah batako yang memiliki densitas $<1800 \mathrm{~kg} / \mathrm{m}^{3}$, nilai kuat tekan dari batako ringan ini terbagi ke dalam tiga kategori yang pertama kategori tinggi yaitu memiliki nilai kuat tekan $>17,3 \mathrm{MPa}$, kategori menengah memiliki rentang nilai 6,9 MPa sampai 17,3 $\mathrm{MPa}$ dan kategori terakhir adalah kategori terendah dengan nilai 0,35 MPa sampai 6,9 $\mathrm{MPa}$. Jenis batako ringan ada dua golongan yaitu: batako ringan berpori (aerated concrete) dan batako ringan aerated (Sunbandri, 2008).

Batako ringan mempunyai keunggulan dan keuntungan adalah sebagai berikut.

a. Lebih mudah dalam hal pengangkutan dan dalam pemasangan.

b. Karena berat batako yang ringan, sehingga proses pemasangan dinding akan lebih cepat dan dapat dilakukan efisiensi waktu pekerjaan.

c. Selain proses pemasangan yang cepat batako ringan juga dapat menghematkan biaya struktur pemikul beban seperti fondasi.

d. Sifatnya lebih detail karena bahan campuran meliputi limbah pengolahan emas, semen, foam, air dan filler pohon pisang.

e. Busa mempunyai sifat isolasi dan akustik yang baik.

Bahan- bahan Penunjang Pembuatan Batako Ringan

1. Semen. Semen merupakan suatu jenis bahan yang memiliki sifat adhesive dan kohesif yang memungkinkan melekatnya fragmen-fragmen mineral lain menjadi suatu massa yang padat. Semen juga mempunyai sifat pozzolan. Sifat pozzolan adalah bahan yang mengandung sifat silica aluminium dimana bentuknya halus dengan adanya air.

2. Foam. Foam yaitu suatu larutan kimia yang banyak digunakan untuk bahan pembuatan batako dan beton yang berfungsi untuk meringankan beratnya suatu batako dan beton. Jenis foam ini berbentuk cair dan warna putih bening. Foam ini ketika dicampurkan dengan air dan diaduk dengan alat pengaduk maka foam ini akan berubah yaitu menjadi busa.

3. Air jernih. Air sangat berperan penting yang digunakan dalam proses pembuatan batako ringan yang kegunaannya untuk melunakkan campuran batako ringan. Air yang digunakan adalah air jernih yang berasal dari sumur.

\section{METODE}

Penelitian diawali dari persiapan bahan penyusunan campuran batako ringan dan peralatan pendukung penelitian. Bahan yang digunakan dalam penelitian adalah limbah pengolahan emas (LPE), filler pohon pisang (fpp), foam dan air. 
Peralatan yang digunakan dalam penelitian adalah timbangan digital, ember, bor pengaduk, gelas ukur, cepang dan cetakan ukuran $9 \mathrm{~cm} \times 9 \mathrm{~cm} \times 9 \mathrm{~cm}$.

Prosedur penelitian pemanfaatan limbah pengolahan emas (LPE) dan filler pohon pisang (FPP) diuraikan sebagai berikut.

1. Tahap persiapan. Mempersiapkan bahan dan peralatan yang digunakan untuk pembuatan batako ringan serta mempersiapkan LPE dan filler pohon pisang yang telah dikeringkan terlebih dahulu.

2. Tahap pencetakan. Untuk membuat campuran batako diperlukan LPE, semen, foam, dan air, pertama campuran semen, LPE dan air terlebih dahulu, kemudian masukkan foam yang telah diaduk bersama air menggunakan bor pengaduk ke dalam campuran semen dan LPE tadi serta timbang adon terlebih dahulu sebelum dicetak dengan ukuran cetakan $9 \mathrm{~cm} \times 9 \mathrm{~cm} \times 9 \mathrm{~cm}$. lakukan pengerasan atau pengeringan di dalam ruangan tanpa sinar matahari.

3. Tahap pengujian. Pengujian uji porositas dan uji kuat tekan, pengujian nilai kuat tekan dapat dilakukan dengan menggunakan alat uji kuat tekan atau alat pres batako ringan sementara untuk uji porositas dapat dilakukan secara manual. Adapun langkah-langkah uji porositas adlah.

a. Sediakan gelas ukur, ember, dan bak, usahakan ember yang digunakan lebih kecil dari pada bak yang akan digunakan.

b. Isikan ember dengan air jernih sampai penuh.

c. Letakkan ember yang telah di isikan air ke dalam bak.

d. Hitunglah volume awal $(V)$ dengan cara $s x s x$ saitu $9 \times 9 \times 9=729 \mathrm{~cm}^{3}$.

e. Hitunglah massa $(m)$ batako ringan menggunakan timbangan digital.

f. Masukkan batako ringan yang telah ditimbang massanya ke dalam ember yang telah diisikan air, tunggulah sampai air di ember benar-benar berhenti jatuh ke dalam bak.

g. Angkatlah ember beserta batako ringan dari dalam bak tersebut.

h. Kemudian hitunglah volume air (volume sebenarnya) yang tumpah ke dalam bak tersebut menggunakan gelas ukur.

i. Catatlah hasilnya di tabel pengamatan.

\section{HASIL DAN PEMBAHASAN}

Hasil perbandingan campuran batako ringan dengan filler pohon pisang didapat hasil seperti disajikan Gambar 1 berikut.

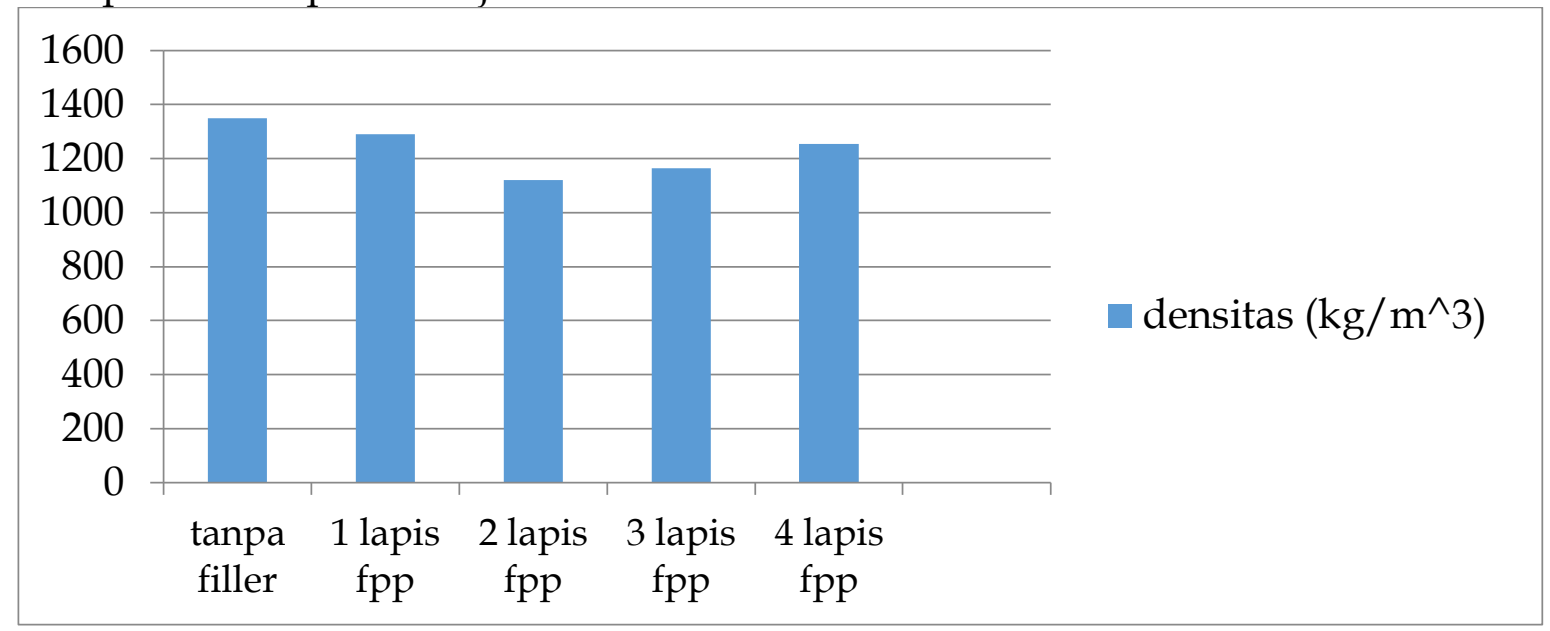

Gambar 1. Grafik uji densitas batako ringan 
Berdasarkan Gambar 1 di atas, menunjukkan bahwa penambahan filler pohon pisang (FPP) berturut-turut: $1349 \mathrm{~kg} / \mathrm{m}^{3}, 1290 \mathrm{~kg} / \mathrm{m}^{3}, 1121 \mathrm{~kg} / \mathrm{m}^{3}, 1163 \mathrm{~kg} / \mathrm{m}^{3}$, $1254 \mathrm{~kg} / \mathrm{m}^{3}$ dengan demikian hasil uji densitas yang dihasilkan bervariasi atau naik turun hal tersebut dipengaruhi oleh proses pencampuran dan peletakan filler pada batako ringan.

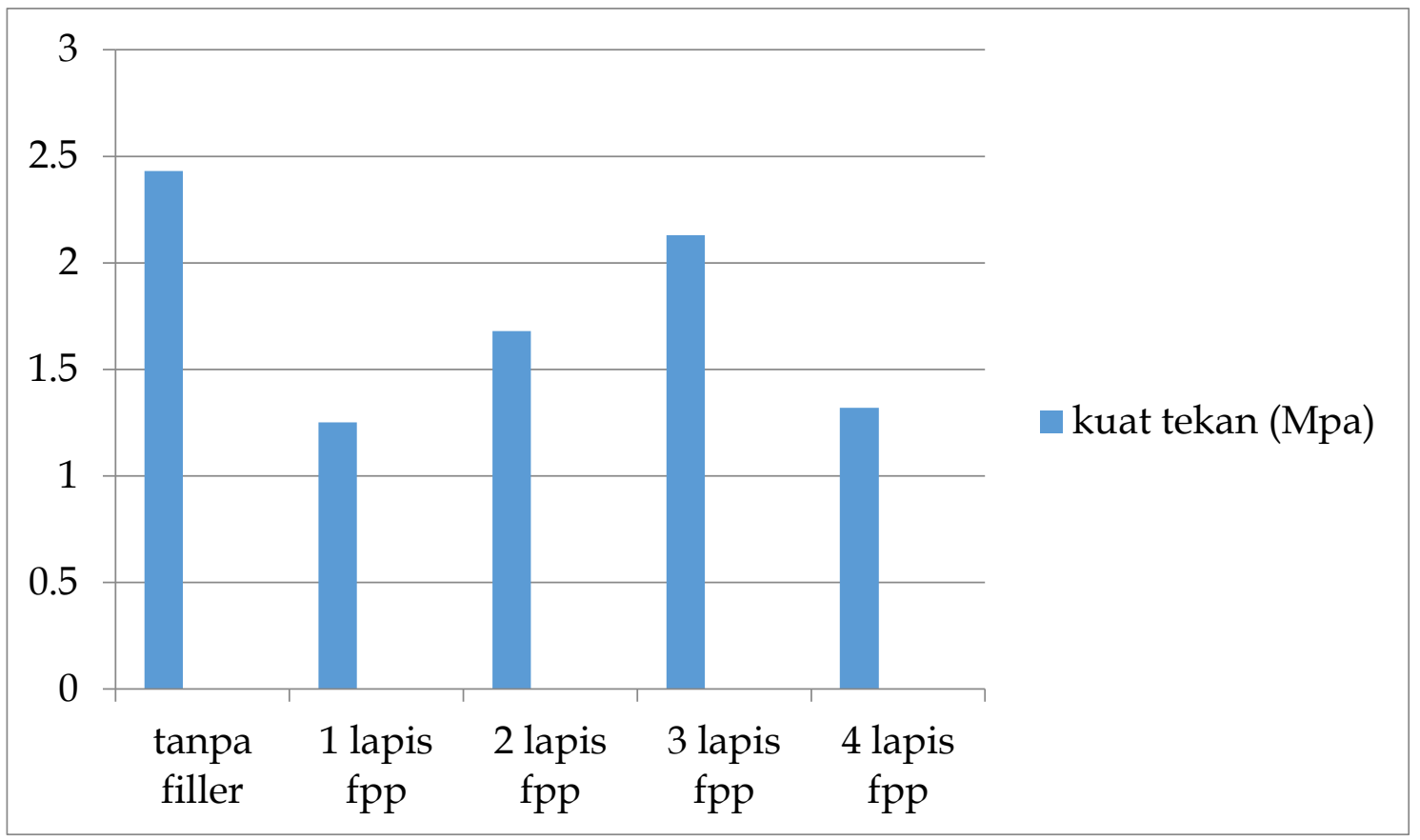

Gambar 2. Grafik uji kuat tekan batako ringan

Berdasarkan Gambar 2 di atas, menujukkan nilai kuat tekan batako ringan berbahan dasar LPE dan filler pohon pisang (FPP) berturut-turut: 2,43 MPa, 1,25 $\mathrm{MPa}, 1,68 \mathrm{MPa}$, 2,13 MPa dan 1,32 MPa nilai yang dihasilkan dari batako ringan dengan filler pohon pisang menunjukkan semakin banyak filler pohon pisang nilai kuat tekan semakin tinggi, hal tersebut dipengaruhi oleh proses pencampuran dan peletakan filler pohon pisang, sehingga pada sampel 5 terjadi hasil yang menurun.

Hubungan Uji porositas terhadap Uji kuat tekan disajikan pada Tabel 1 berikut.

Tabel 1. Hubungan Uji porositas terhadap Uji kuat tekan

\begin{tabular}{cccc}
\hline Sampel & Komposisi & Poros (\%) & Kuat tekan (MPa) \\
\hline 1. & Tanpa Fpp & 24 & 2,43 \\
2. & 1 Lapis Fpp & 31 & 1,25 \\
3. & 2 lapis Fpp & 17 & 1,68 \\
4. & 3 Lapis Fpp & 17 & 2,13 \\
5. & 4 Lapis Fpp & 31 & 1,32 \\
\hline
\end{tabular}

Tabel 1 menunjukkan bahwa hubungan uji porositas terhadap kuat tekan berbanding terbalik, yaitu semakin tinggi nilai kuat tekan maka nilai uji porositas yang dihasilkan semakin kecil. Berdasarkan hasil uji tekan bata ringan berbahan dasar limbah pengolahan emas hasil penelitian ini memiliki kuat tekan rata-rata 7,8 $\mathrm{kg} / \mathrm{cm}^{2}$ (Prasetya dkk., 2017). 
Berdasarkan hasil penelitian dan analisa dapat direkomendasikan bahwa untuk mendapatkan porposi campuran batako yang tepat dari kedua bahan limbah tersebut ditinjau terhadap kekuatan yaitu menggunakan praksi BT10 (10\%), Sedangkan biaya produksi untuk praksi BT10 (10\%) lebih murah 33\% bila dibandingkan dengan biaya produksi pada batako konvensional (Sujatmiko \& Nizarsyah, 2015). Dalam arah ortogonal, kuat tekan adalah $(2,43 ; 0,26 ; 0,80 ; 0,63$; $0,77) \mathrm{MPa}$ dengan kepadatan $(1,62 ; 1,42 ; 1,49 ; 1,53 ; 1,42) \mathrm{gr} / \mathrm{cm}^{3}$. Sedangkan dalam arah acak kekuatan tekan adalah $(2,43 ; 0,73 ; 0,69 ; 0,59 ; 0,65) \mathrm{MPa}$ dengan kepadatan $(1,62 ; 1,20 ; 1,41 ; 1,13 ; 1,20) \mathrm{gr} / \mathrm{cm}^{3}$. Dari data ini dengan membandingkan dengan penelitian sebelumnya, nilai kuat tekan dan densitas yang paling stabil dibentuk dalam arah ortogonal. Sedangkan nilai kerapatan paling banyak terbentuk dalam arah acak. Di semua arah, kekuatan tekan dan kerapatan stabil terbentuk pada volume pengisi $60 \%$. Hasil tes menunjukkan bahwa batu bata ringan yang dibentuk ke dalam kategori sangat ringan (masuk dalam kisaran 0,6 - 1,6 gr $/ \mathrm{cm}^{3}$ ) dan mengambang di air, dengan kekuatan tekan sedang (Pangga dkk., 2018)

\section{KESIMPULAN}

Penambahan filler pohon pisang (fpp) dalam pencampuran batako ringan dapat mempengaruhi nilai porositas dan nilai kuat tekan batako ringan yaitu semakin banyak komposisi filler pohon pisang (FPP) maka nilai porositas yang dihasilkan bervariasi sementara nilai kuat tekan yang dihasilkan semakin tinggi.

\section{SARAN}

Proses pembuatan batako ringan lebih baik dibuat dalam satu hari untuk semua sampel yang dibutuhkan, sehingga pada saat pengujian antara uji densitas dan uji porositas akan didapatkan data yang baik.

\section{DAFTAR PUSTAKA}

Balitbang. 2017. Standar Bata Beton Untuk pemasangan Dinding. Jakarta: Departemen Pekerjaan Umum.

Pangga, D., Prasetya, D. S., \& Ahzan, S. (2018). Pengembangan bata ringan berbahan dasar limbah pengolahan emas tradisional dengan penguat eceng gondok. Lensa: Jurnal Pendidikan Fisika, 6(2), 90-96.

Prasetya, D. S., Priyambodo, S., \& Ahzan, S. (2017). Pembuatan bata ringan berbahan dasar limbah pengolahan emas tradisional di Propinsi NTB. Lensa: Jurnal Pendidikan Fisika, 4(2), 1-3.

PU, D. P. (1989). Bata Beton Untuk Pasangan Dinding. Jakarta: .Badan Standarisasi Nasional.

Riogilang, H. (2009). Pemanfaatan Limbah Tambang Untuk Bahan Konstruksi Bangunan, Ekoton, 9(1), 69-73.

Samua, H. (2009). Karakteristik Untuk Tambang Emas Rakyat Dimembe Kabupaten minahasa Utara. Manado, Laporan Penelitian Jurusan Teknik Elektro Fakultas Teknik UNIMA Manado.

Subandri. (2008). Kajian Bahan Pencemaran Merkuri (Hg) Terhadap Air Sungai Menyuke Dan Gangguan Kesehatan Pada Penambangan Sebagai Akibat Penambangan Emas Tanpa Izin (Peti) dikecamatan Menyuke. Tesis. Semarang: Magister Kesehatan Lingkungan Universitas Diponogoro. 
Sujatmiko, B., \& Nizarsyah, F. (2015). Analisis Pemanfaatan Bahan Limbah Pada Campuran Batako Ditinjau Terhadap Kekuatan dan Biaya, Jurnal Teknik Sipil Unitomo, 1(1), 13-19.

Tjokrodimulyo, K. (2007). Teknologi beton. Yogyakarta: Biro penerbit KMT FT UGM.

Wikipedia. Batu bata. Retrieved from Wikipedia: https://id.wikipedia.org/wiki/Batu_bata 